\title{
Long-term analysis of snow-covered area in the Moroccan High-Atlas through remote sensing
}

\author{
A. Boudhar ${ }^{a, *}$, B. Duchemin ${ }^{\text {b }}$, L. Hanich ${ }^{a}$, L. Jarlan ${ }^{\text {b }}$, A. Chaponnière ${ }^{c}$, P. Maisongrande ${ }^{b}$, \\ G. Boulet ${ }^{\mathrm{b}}$, A. Chehbouni ${ }^{\mathrm{b}}$ \\ ${ }^{a}$ Faculté des Sciences et Techniques de Marrakech, Av. A. Khattabi, BP 549, Marrakech, Morocco \\ ${ }^{\mathrm{b}}$ CESBIO (Université de Toulouse, CNRS, CNES, IRD), 18 Av. Edouard Belin, BPI 280, Toulouse cedex 4, France \\ ${ }^{\mathrm{C}}$ IWMI-West Africa, PMB CT 112, Cantonments, Accra, Ghana
}

A R T I C L E I N F O

\section{Article history:}

Received 20 November 2008

Accepted 7 September 2009

\section{Keywords:}

High-Atlas

Snow cover

Optical remote sensing

SPOT-VEGETATION

Snow Index

Nival hydrology

\begin{abstract}
A B S T R A C T
The High-Atlas mountainous region in Morocco is a true water tower for the neighbouring arid plains, where the water resources are intensively and increasingly subjected to exploitation for agriculture and tourism. In order to manage this resource sustainably, it is necessary to describe accurately all the processes that contribute to the hydrological cycle of the area, and, in particular, to know the respective contributions of liquid and solid precipitations to runoff. In this context, a seven-year time series of SPOT-VEGETATION images is used for mapping snow-covered areas. The spatial and temporal variations of the snow cover are analyzed for the entire High-Atlas region as well as by altitudinal zones. The spatial distribution of snow-covered areas appears logically controlled by elevation, and its temporal fluctuations can be clearly used to identify dry and wet seasons. In addition, a possible control of snowfalls by the Northern Atlantic climate variability, and, in particular, the North Atlantic Oscillation, is highlighted. Finally, this study shows how satellite remote sensing can be useful for the long-term observation of the intra- and inter-annual variability of snowpacks in rather inaccessible regions where the network of meteorological stations is deficient.
\end{abstract}

\section{Introduction}

Snowfall and snowmelt are fundamental processes of the hydrological cycle. The space-time dynamic of snowpacks is an indicator of the climatic change (Bloschl, 1999). Its knowledge is necessary for hydrological modelling (Liston, 1999).

In arid and semi-arid regions, mountainous areas are important water sources, not only for upland regions, but also for adjacent lowlands where rivers supply water for irrigation, industrial or other water uses. In some Mediterranean regions, an important percentage of the available water is accumulated in the form of snow before the melting season. In Lebanon, for example, water from snowmelt contributes roughly to two-thirds of the annual volume of water supplies (Shaban et al., 2004). In the surrounding of High-Atlas mountains in Morocco, the irregular nature of precipitations, combined with a high evaporation rate, makes the monitoring and management of water resources difficult (World Bank, 1995). Consequently, it is important to thoroughly under-

\footnotetext{
* Corresponding author.

E-mail address: boudhar22@yahoo.fr (A. Boudhar).
}

stand the processes and variables which control the hydrological cycle in these areas. In particular, previous studies show the importance of the contribution of snowmelt to the stream flows for the main wadis in the region (Abidi, 1989; Schulz and De Jong, 2004; Chaponnière et al., 2005, 2008; Boulet et al., 2008). In this context and within the framework of the SudMed project (Chehbouni et al., 2008), we investigate the possibility of using remote sensing data to quantify the spatial and temporal dynamics of snow-covered areas (SCA) in the Moroccan High-Atlas mountainous region.

Satellite imagery provided by low spatial resolution sensors is a tool specifically adapted to regional studies. It allows the acquisition of observations regularly distributed in time and space (NOAA-AVHRR since 1980, TERRA-MODIS and SPOT-VEGETATION since the late 1990s). The optical domain of the electromagnetic spectrum is well suited for the identification of SCA because the optical properties of snow are very specific. Snow and ice are characterized by a high reflectance in the visible and near infra-red parts of the electromagnetic spectrum, and a high absorption in the middle infra-red part. These properties have allowed the mapping of SCA from various optical sensors (Rosenthal and Dozier, 1996; Simpson et al., 1998; Salomonson and Appel, 2004; Chaponnière 
et al., 2005). Monitoring the dynamics of SCA requires high frequency data coverage such as those coming from large field-ofview sensors, which allow almost daily observation of the Earth. This is the case of the SPOT-VEGETATION observations used here.

The main question addressed in this research is how long time series of satellite observations can be used for the reconstruction of the intra- and inter-annual variability of snow-covered areas in mountainous semi-arid regions? To address this question, we used a seven-year archive (1998-2005) of SPOT-VEGETATION data acquired over the High-Atlas region. After describing the study area, we present the methodology used to monitor SCA from SPOTVEGETATION images. The space-time variability of the snow extent is studied at the scale of the High-Atlas, both globally and by altitudinal zones. A first attempt to link the inter-annual variability of SCA with the Northern Atlantic Oscillation is finally presented.

\section{Materials and methods}

\subsection{Study area}

The High-Atlas is a Moroccan mountainous chain of approximately $60 \mathrm{~km}$ in width and $800 \mathrm{~km}$ in length organized along a NESW axis. It culminates at an altitude of $4167 \mathrm{~m}$ at the Jbel Toubkal, the highest summit of North Africa (Fig. 1). The vegetation is generally sparse and is growing mainly at the bottom of the valleys. This makes easier the identification of snowy areas.

The study area is located several ten kilometres at the southeast of the Marrakech city (Fig. 1), between latitudes $30^{\circ} 52^{\prime} 12^{\prime \prime}$ and $31^{\circ} 39^{\prime} 36^{\prime \prime}$ North, longitudes $7^{\circ} 13^{\prime} 12^{\prime \prime}$ and $8^{\circ} 40^{\prime} 12^{\prime \prime}$ West, and at altitudes higher than $1000 \mathrm{~m}$. This is the central part of the Moroccan High-Atlas, which is the water tower for the arid plains of the Haouz in the north and of the Souss in the southwest, as well as the valleys of Drâa and Dadès in the southeast. For the 19892007 period, the annual average precipitation is $610 \mathrm{~mm}$ in the Oukaimden CAF station at $2650 \mathrm{~m}$ altitude, whereas it is only $200 \mathrm{~mm}$ at the Marrakech station in the plain (elevation of $450 \mathrm{~m}$ ). The proportion of precipitations that falls as snow is significant: at the CAF station, rainfall and snowfall are around 240 and $370 \mathrm{~mm}$, respectively.

\subsection{SPOT-VEGETATION data}

The VEGETATION sensors, launched onboard the SPOT- 4 and -5 satellites, include an imaging system in four spectral bands from the blue $(\sim 0.45 \mu \mathrm{m})$ to the middle infra-red $(\sim 1.67 \mu \mathrm{m})$. The fieldof-view is $0-55^{\circ}$ on both sides of the satellite tracking path, allowing the acquisition of data on a swath of approximately $2200 \mathrm{~km}$. The pixel size is $1.15 \mathrm{~km} \times 1.15 \mathrm{~km}$ at nadir. The SPOT satellites follow a polar heliosynchronous orbit at an altitude of approximately $830 \mathrm{~km}$. Their period of revolution is $101 \mathrm{~min}$ and their orbital repeat cycle is 26 days. These technical characteristics allow the VEGETATION instrument to see the High-Atlas region almost each day.

In this study we used the SPOT-VEGETATION $\mathrm{P}$ product ("Primary Product", see Maisongrande et al., 2004), which includes data as seen by the sensor at each orbit pass. The recorded radiations are calibrated and standardized from incident light energy. The digital counts represent the apparent reflectance at the top of the atmosphere. The images are corrected for geometrical effects and presented in a geographical projection where each pixel corresponds to a square with a side measuring 1 / $112^{\circ}$.

More information on the data and their pre-processing is available in Duchemin and Maisongrande (2002), Maisongrande
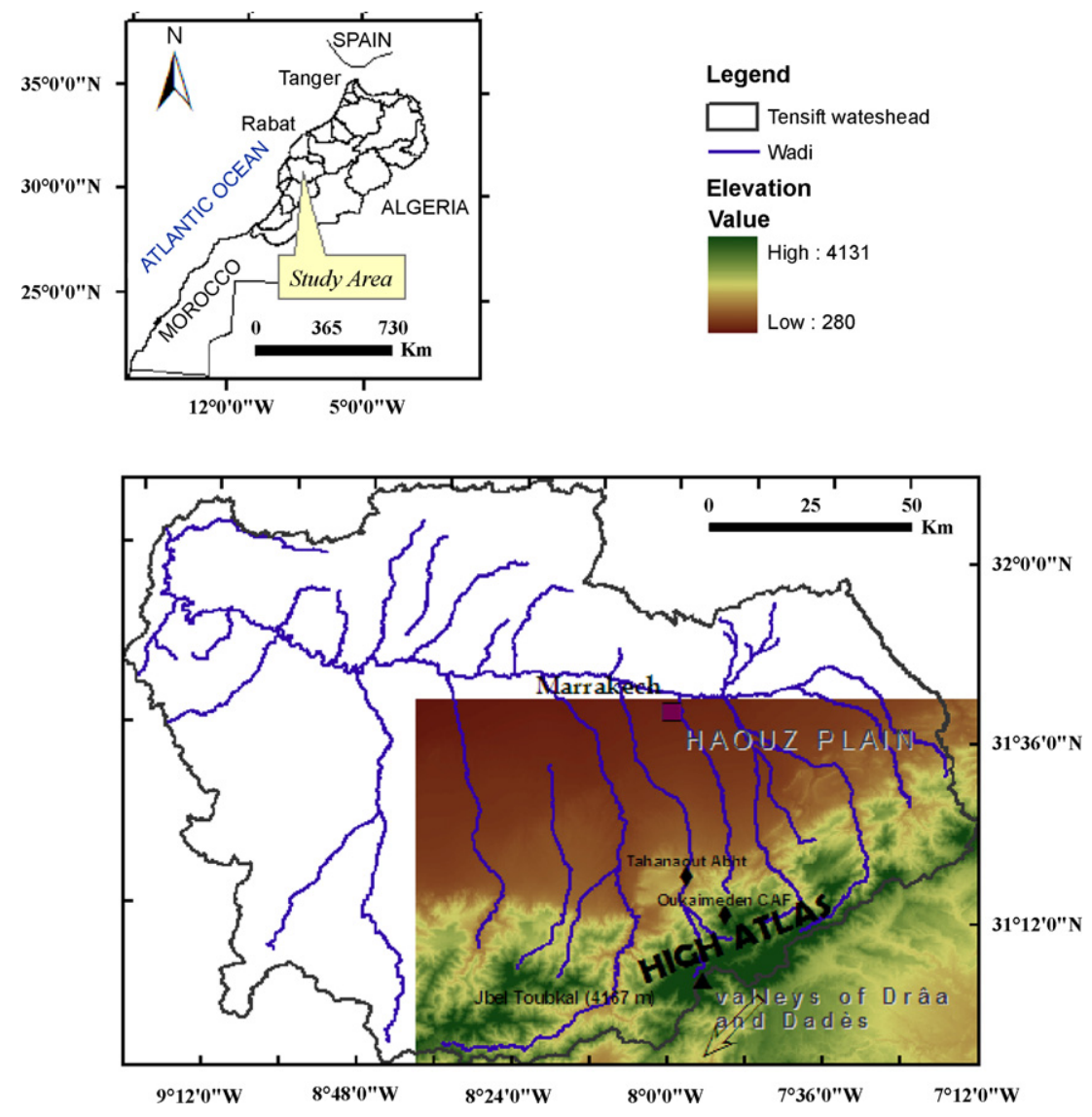

Fig. 1. Location and topography of the study area. 
et al. (2004) and Hagolle et al. (2005), as well as the following website: www.spot-vegetation.com, www.vegetation.cnes.fr, and www.spotimage.fr.

\subsection{Selection of cloud-free images}

The archive of SPOT-VEGETATION $\mathrm{P}$ products covers the hydrological years between 1998-1999 and 2004-2005 from September 1 to June 30, which means approximately 300 images per season. For the study area, the size of the images is 191 lines by 280 columns $\left(\sim 53,000 \mathrm{~km}^{2}\right)$.

The remarkably irregular relief of the High-Atlas Mountains causes difficulties in the interpretation of the images acquired with large viewing angles. We have therefore only kept images acquired with a view zenith angle less than $23^{\circ}$. This leads to selection of 8 images every 26 days and limits both geometrical (change in the observed surfaces depending on exposures and slopes) and directional (change in reflectances according to the sun-targetsensor geometry) effects.

To select cloud-free data, we initially eliminated the images showing high reflectances over the lower-lying areas close to High-Atlas mountains. A threshold of $20 \%$ was applied after averaging blue reflectances on approximately 5000 pixels snow-free, i.e. $10 \%$ of the study area with altitude lower than $1000 \mathrm{~m}$. High reflectances are due the presence of clouds on the Atlas foothills, and therefore, almost certainly, on the Atlas mountains as well. In a second phase, we performed a visual examination to identify partial or thin clouds on the remaining images.

The number of images retained after passing through the two phases of selection is $36,34,23,24,35,37$ and 34 for years 1998 1999, 1999-2000, 2000-2001, 2001-2002, 2002-2003, 20032004 and 2004-2005, respectively. The number of useful observations is, on average, the equivalent of 1 image every week, albeit strong disparities regarding their temporal distribution.

\subsection{Estimate of snow-covered areas}

The calculation of the snow-covered areas is based on a Snow Index (SI, Eq. (1)) which uses reflectances from the blue $\left(B_{0}\right)$, red $\left(B_{2}\right)$ and medium infra-red (MIR) channels of the VEGETATION sensor (Lissens et al., 2000). This index has been retained following a comparison of several other algorithms over the Moroccan HighAtlas (Hanich et al., 2003; De Solan et al., 2002). It was subsequently improved to reduce the influence of the variations of the spectral signature of the ground through the calculation of a Modified Snow Index (MSI, Eq. (2), after Chaponnière et al., 2005). The MSI limits this influence using the snow indices of totally snow-free surfaces ( $\mathrm{SI}_{0}$, computed, for each pixel, from images acquired in summer) and of pixels totally covered with snow $\left(\mathrm{SI}_{100}\right.$, one single value computed as the maximum of SI on images acquired during winter).

$\mathrm{SI}=\frac{B_{0}+B_{2}}{2}-\mathrm{MIR}$

$\mathrm{MSI}=\mathrm{SI}-\mathrm{SI}_{0} \frac{\mathrm{SI}_{100}-\mathrm{SI}}{\mathrm{SI}_{100}-\mathrm{SI}_{0}}$

The area covered with snow $\left(S_{\mathrm{HOR}}\right.$, Eq. $\left.(3)\right)$ in each pixel was calculated by applying the exponential relationship established by Chaponnière et al. (2005) after combining the analysis of SPOT-VEGETATION data with high-resolution spatial (LandsatTM) images. The factor 0.84 in Eq. (3) converts the area in $\mathrm{km}^{2}$; without this correction, Eq. (3) provides the relative percentage of the surface covered by snow in each pixel, expressed between
0 and 1.

$S_{\mathrm{HOR}}=0.84\left[1-0.49 \exp \left(-0.69 \frac{\mathrm{MSI}}{100}\right)+1\right]^{20}$

\subsection{Topographic correction}

To approximate the actual extent of snow-covered areas, we performed an additional correction using a digital elevation model (DEM) to account for the slopes in the calculation of the snowcovered areas (Eq. (4)). The DEM came from the radar interferometry data gathered during the 10 day mission of the Endeavour Space Shuttle (freely available at http://seamless.usgs.gov/Website/Seamless/, with a spatial resolution of $90 \mathrm{~m}$ ). The correction was made using a mean slope, degraded from $90 \mathrm{~m}$ to the resolution of SPOT-VEGETATION data by simple averaging. The DEM was also used to partition the study area into $400 \mathrm{~m}$ elevation zones from 1000 to $4200 \mathrm{~m}$.

$S=\frac{S_{\mathrm{HOR}}}{\cos (\text { mountain slope })}$

where $S$ is the actual snow-covered area.

\section{Results and discussion}

\subsection{Spatio-temporal variability of snow-covered areas}

Fig. 2 shows an example of three VEGETATION images acquired during winter 2005 and the resulting snow maps obtained after the application of Eq. (3). Snow-covered areas are clearly identifiable in the VEGETATION images (in blue in Fig. 2a-c). (For interpretation of the references to colour in this text, the reader is referred to the web version of this article.) Snow-covered area increases considerably from February 22 to March 6, 2005 after a snowfall event and decreases thereafter until March 21 during a snowmelt period (Fig. $2 \mathrm{~d}-\mathrm{f}$ ). The spatial distribution appears from a first analysis to be primarily controlled by elevation (see the DEM in Fig. 1).

Fig. 3 shows the seasonal variations of the SCA accumulated over the whole study area for hydrological seasons 1998-1999 to 2004-2005. The episodes of snowfall are marked by peaks of snowcovered areas, whereas melting periods are generally characterized by a very important reduction of SCA (e.g. a decrease from 2600 to $350 \mathrm{~km}^{2}$ from January 17 to 27,2003 ). Table 1 summarizes the main features of the snow cover from the satellite observations. These results highlight the strong seasonal and inter-annual variability of snowpacks in the region:

- The presence of snow is always detected in winter, but over markedly variable areas, with a maximum of snow-covered surfaces of $1750 \mathrm{~km}^{2}$ for the season $1999-2000$ against more than $4600 \mathrm{~km}^{2}$ for the season 2005-2006.

- The number of snowfall episodes detected each season varies between one (1999-2000) and five (2002-2003 and 20042005); the melting periods are dominant, including in the very midst of the winter season.

- The period separating the first from the last snowfall (peaks of snow-covered surfaces) is also quite variable; the first snowfalls are observed between the end of September (1998-1999) and the end of December (2000-2001), while the last snowfalls are recorded between the end of January (2000-2001) and the beginning of April (2003-2004).

From these facts, we can also make a distinction between two groups of seasons: three wet winters (1998-1999, 2003-2004 and 20042005), marked by a seasonal average snow coverage of about 

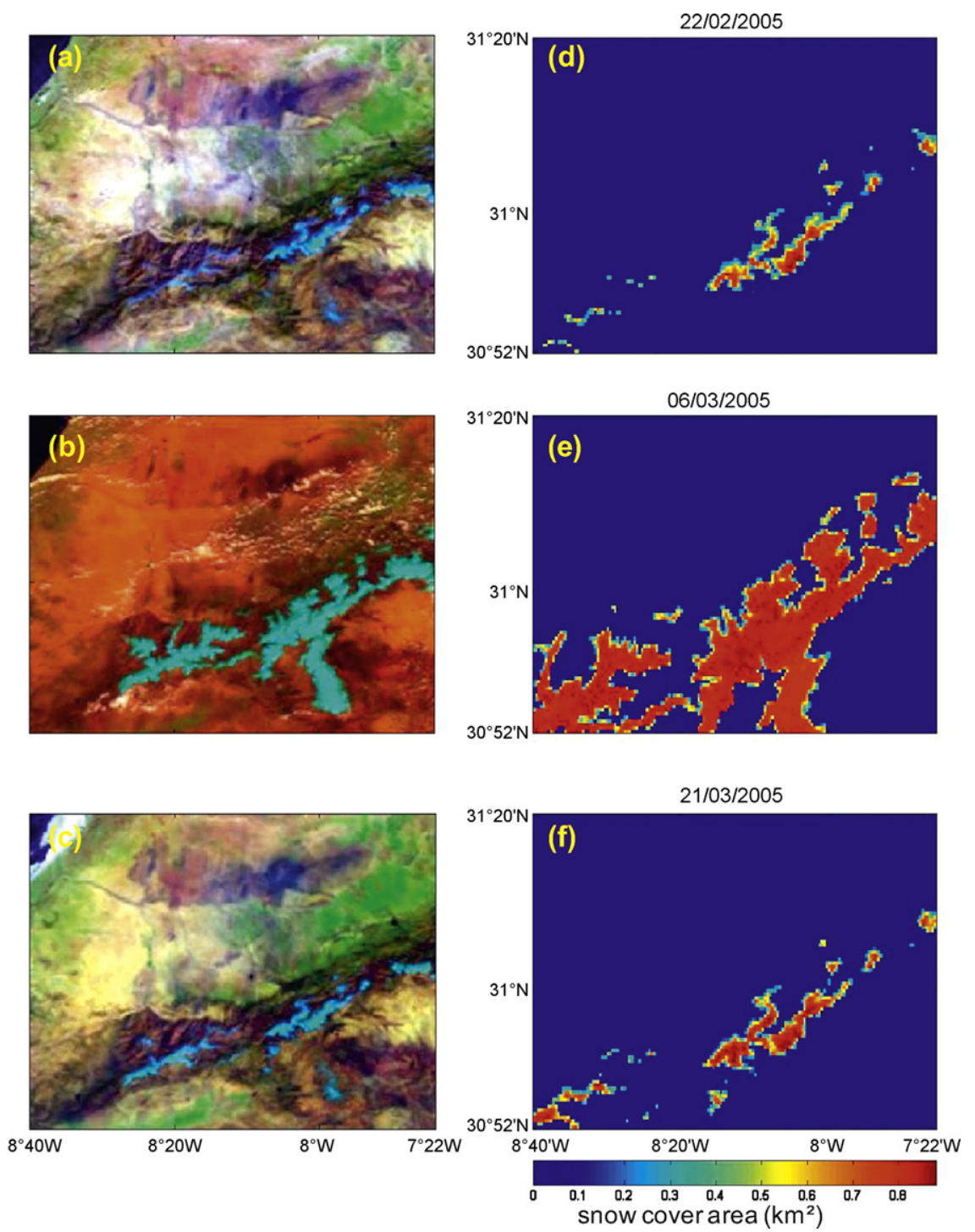

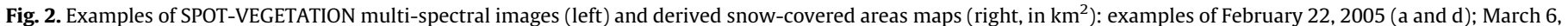
2005 (b and e) and March 21, 2005 (c and f).
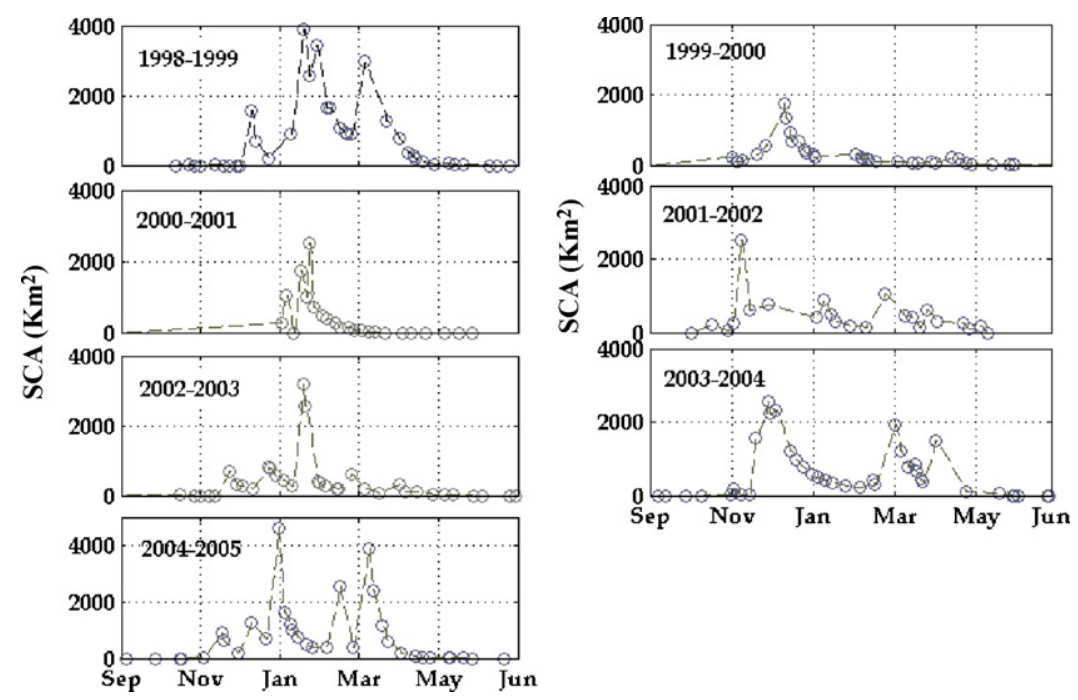

Fig. 3. Dynamics of snow-covered areas at the scale of the High-Atlas from seasons 1998-1999 (top-left) to $2004-2005$ (bottom-left).

Please cite this article in press as: Boudhar, A., et al., Long-term analysis of snow-covered area in the Moroccan High-Atlas through remote sensing. Int. J. Appl. Earth Observ. Geoinform. (2009), doi:10.1016/j.jag.2009.09.008 
Table 1

Main characteristics of snow-covered areas observed by SPOT-VEGETATION at the scale of High-Atlas from seasons 1998-1999 to 2005-2006.

\begin{tabular}{|c|c|c|c|c|c|}
\hline \multirow[t]{2}{*}{ Season } & \multirow{2}{*}{$\begin{array}{l}\text { Number of } \\
\text { snowfall events }\end{array}$} & \multirow[t]{2}{*}{ First and last snowfall event } & \multicolumn{2}{|c|}{ Maximal snow-covered areas } & \multirow{2}{*}{$\begin{array}{l}\text { Seasonal mean } \\
\text { snow-covered areas }\left(\mathrm{km}^{2}\right)\end{array}$} \\
\hline & & & Surface $\left(\mathrm{km}^{2}\right)$ & Date & \\
\hline 1998-1999 & 4 & December 7-April 10 & 3900 & January 16 & 779 \\
\hline 1999-2000 & 2 & September 20-February 18 & 1745 & October 11 & 312 \\
\hline 2000-2001 & 3 & December 30-February 19 & 2512 & January 20 & 385 \\
\hline 2001-2002 & 4 & October 16-April 22 & 2518 & November 7 & 431 \\
\hline $2002-2003$ & 5 & November 21-March 29 & 3168 & January 16 & 379 \\
\hline 2003-2004 & 3 & November 2-April 23 & 2564 & November 28 & 671 \\
\hline 2004-2005 & 5 & November 15-April 11 & 4620 & December 28 & 750 \\
\hline
\end{tabular}

$670 \mathrm{~km}^{2}$, and four dry winters (1999-2000 to 2002-2003) characterized by a lesser extent of SCA (on average $430 \mathrm{~km}^{2}$ ). However, these results must be considered with care because they partly depend on the availability of cloud-free images. For instance, there are long periods without any observations, e.g. from September to December, 2000. Thus, because the snowmelt can be rapid, it is possible that some snowfall events have not been detected. On the other hand, these events are only detected if they correspond to an increase of snow-covered areas, which is not the case when it snows on already existing snowpack. Nevertheless, the result of this classification between dry and wet season appears consistent with the regional climatic features. Indeed, for the three wet seasons, the annual precipitation recorded at the Tahanaoute station was around $500 \mathrm{~mm} /$ year, while it was lower than $300 \mathrm{~mm} /$ year for the four dry seasons.

Fig. 4 shows a more detailed analysis of snow-covered areas during the 2004-2005 season, for which the dynamics of SCA was the most important. We note, very logically, that the rate of snow coverage increases with altitude, as well as the non-permanent character of the snowpack. During the winter period, i.e. from November 15, 2004 to April 1, 2005, snow-covered areas represent more than $30 \%$ of surfaces with altitudes between 3000 and $3400 \mathrm{~m}$, and more than 50\% for altitudes higher than $3400 \mathrm{~m}$. In contrast, the snowpack totally disappears at altitudes lower than $2600 \mathrm{~m}$ (see the estimates from January 18 to February 2, 2005). The melting period can be very short at these lower altitudes: for instance, the snowpack almost totally disappeared in 6 days (from December 28, 2004 to January 2, 2005) for the 1800-2200 m altitudinal section. The snow ablation process (melt and sublimation) may be also important at higher elevations (see the period from December 28, 2004 to January 22, 2005). This analysis also allows identifying differences in snow ablation process at different elevations. As an example from January 7 to 18,2005 , SCA remains stable over the highest elevation $(>3400 \mathrm{~m})$ while a general decrease is observed at the lower altitudinal sections.

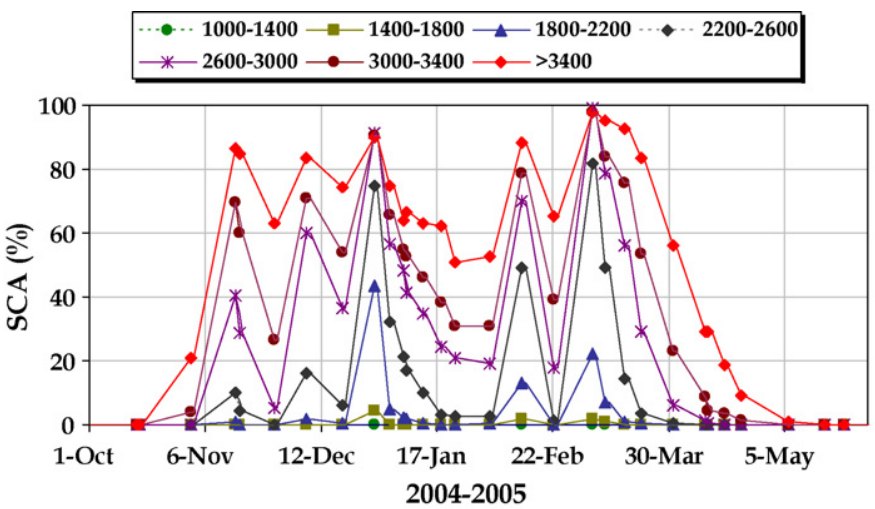

Fig. 4. Variations of snow-covered areas during the 2004-2005 hydrological season at various altitudinal zones from 1000 to $4200 \mathrm{~m}$.

\subsection{Possible linkage of SCA with climate}

In order to explain the inter-annual variability of snow-covered areas, we carried out a simple composite analysis (Von Storch and Zwiers, 1999) of the Sea Level Pressure (SLP) over the Northern Atlantic. Within this study, data are taken from the NCEP/NCAR reanalysis (Kalnay et al., 1996). This analysis aims to provide with differences of atmospheric conditions between wet and dry years.

Fig. 5 displays the composite difference of SLP anomaly over the northern Atlantic between the wet (1999, 2004 and 2005) and the dry (2000-2003) seasons detected from remotely sensed SCA. The figure is provided by the NOAA/ESRL Physical Sciences Division, Boulder Colorado (see www.esrl.noaa.gov/psd). Its analysis points out that the East Atlantic (EA) pattern could be a potential control on winter temperature and precipitation over the Atlas, and thus on SCA. The EA pattern is the second leading mode of low-frequency climate variability over the North Atlantic and displays a north-south dipole of anomaly centers spanning the North Atlantic from east to west (Barnston and Livezey, 1987). It is strongly associated to the North Atlantic Oscillation (NAO). Through east-west oscillation motions of the Icelandic low temperature/pressure and the Azores high temperature/pressure, the NAO controls the strength and direction of westerly winds and storm tracks across the North Atlantic. NAO impacts many parts of the word (Hurrell, 1995). As it is a winter phenomenon, it has a high potential impact on processes that occur in winter such as snowfall in the northern hemisphere. Positive phases of NAO (positive anomaly over the Azores and negative anomaly over the Iceland) lead to increased westerly winds and, consequently, mild and wet winters in Central Europe. In contrast, during negative phases of NAO (positive anomaly over Iceland and negative anomaly over the Azores), westerly winds are suppressed, Central Europe experiences cold winters and storms track southerly toward the Mediterranean Sea. This brings increased storm activity and rainfall to southern Europe and North Africa, and, in particular, over Morocco (Knippertz et al., 2003).

The composite analysis shown in Fig. 5 corroborates the potential control of EA pattern and NAO oscillation over SCA in the Atlas Mountains: wet years (1998-1999, 2003-2004 and 20042005) are characterized by higher SLP over Iceland and lower SLP over the Azores region than dry years (1999-2003), thus reinforcing the southern position of the storms track activity to southern Europe and northern Africa. However, the short length of the time series (1998-2005) precludes from carrying out a more in-depth diagnostic analysis.

\subsection{Conclusion and perspectives}

This study shows the possibility of observing the dynamics of the snowfall and snowmelt cover within the semi-arid HighAtlas Mountains, based on long-term satellite imagery (SPOTVEGETATION, 1998-2005). In addition to the identification of relatively dry seasons and wet seasons, the interest of such 


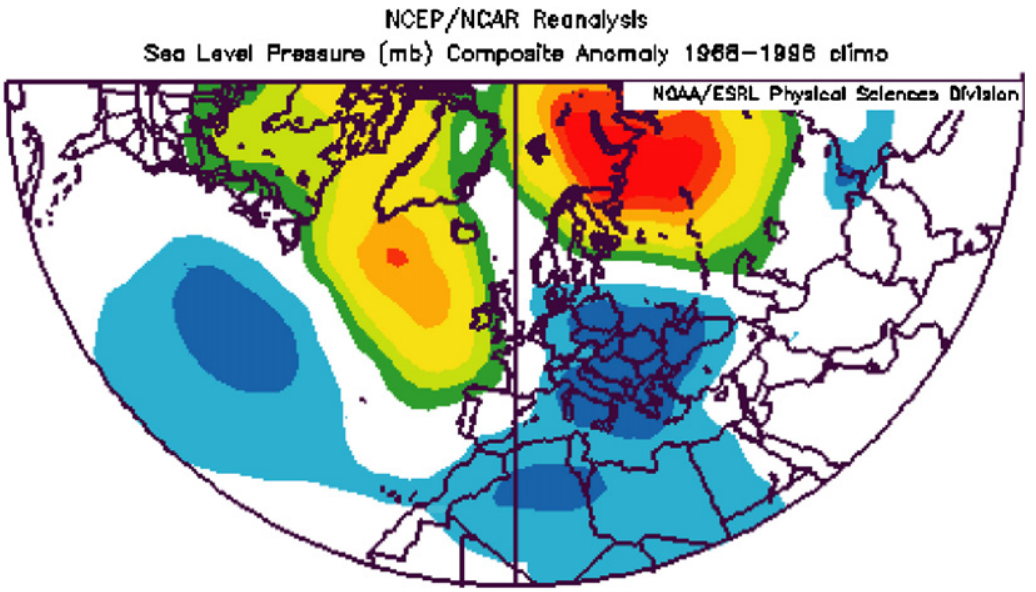

Jan to Mor: : 1999,2004,2005 minua 2000,2001،2002,2003

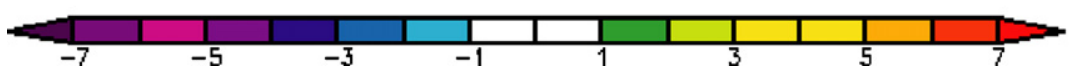

Fig. 5. Composite difference of Sea Level Pressure (averaged from January to March) anomaly over the wet (1999, 2004 and 2005) and the dry (2000-2003) seasons.

observations is even greater given the high spatial and temporal variability of snowpacks. This information may significantly reinforce the information derived from the climatic network, generally not very consistent or reliable in the high mountains, despite the fact that precipitations in such environments are often local and heavy.

In addition, a preliminary study of the linkages between the inter-annual variability of SCA and climate has been carried out. The composite analysis of the Northern Atlantic SLP points out to the East Atlantic Pattern and the North Atlantic Oscillation as a potential control. Long-term observation of snow-covered areas by means of remote sensing can thus (1) provide new information for the evaluation of the impact of climatic changes on the seasonal and inter-annual variations of precipitations and (2) provide a better understanding on the dynamic of SCA over this region and, in particular, its potential control by climatic pseudo-oscillations (NAO).

This research also opens perspectives for the comprehension of the hydrological cycle of the High-Atlas catchments. One might here expect testing methods for data assimilation in hydrological models to assist in the forecasting of base flows or flood risks. SCA products can be used to evaluate the contribution of snowmelt rate to the streamflow through hydrological modelling (see our study based on the SRM model over the five atlasic sub-catchment, Boudhar et al., in press). Obviously, such information derived from remote sensing observations with a high repeatitivity can be of great interest for operational planning of water use (reinforcement of the monitoring of precipitations, identification of the dry and wet years, relation between snowfall and flow rates, etc.).

\section{Acknowledgements}

This research took place within the framework of SUDMED project and with the support of the French-Morrocan Committee (Integrated Action No. MA/06/148) within the Young Team Associated of the IRD (CREMAS). The authors are grateful to ABHT (Agence de Bassin du Haouz-Tensift, Marrakech, Morocco) for the acquisition of the hydro-meteorological data on the Tensift watersheds. VEGETATION images were provided by initiative of the VEGETATION Programme. We also wish to extent our gratitude to the reviewers for their constructive comments on the manuscript. We would like to thank especially Dr. Ross Brown for the delivery of the Sea Level Pressure product and the help on the composite analysis.

\section{References}

Abidi, A., 1989. Martinec-Rango Snowmelt Runoff Model applied to the Tillouguite Basin of Morocco, Master Thesis, School of Mines and Technology, South Dacota.

Barnston, A.G., Livezey, R.E., 1987. Classification, seasonality and persistence of lowfrequency atmospheric circulation patterns. Monthly Weather Review 115, 1083-1126.

Bloschl, G., 1999. Scaling issues in snow hydrology. Hydrological Processes 13, 2149-2175.

Boudhar, A., Hanich, L., Boulet, G., Duchemin, B., Chehbouni, A., in press. Impact of the snow cover estimation method on the Snowmelt Runoff Model performance in the Moroccan High Atlas Mountains. Hydrological Sciences Journal/Journal des Sciences Hydrologiques.

Boulet, G., Boudhar, A., Hanich, L., Duchemin, B., Simonneaux, V., Maisongrande, P., Chehbouni, A., Thomas, S., Chaponnière, A., 2008. Hydrological modelling in the High Atlas mountains with the help of remote-sensing data: milestones of the SudMed project. In: 13th IWRA World Water Congress 2008, 1-4 September, Montpellier, France.

Chaponnière, A., Maisongrande, P., Duchemin, B., Hanich, L., Boulet, G., Halouat, S., Escadafal, R., 2005. A combined high and low spatial resolution approach for mapping snow covered area in the Atlas Mountain. International Journal of Remote Sensing 26, 2755-2777.

Chaponnière, A., Boulet, G., Chehbouni, A., Aresmouk, M., 2008. Understanding hydrological processes with scarce data in a mountain environment. Hydrological Processes 22, 1908-1921.

Chehbouni, A., Escadafal, R., Boulet, G., Duchemin, B., Simonneaux, V., Dedieu, G Mougenot, B., Khabba, S., Kharrou, H., Merlin, O., Chaponnière, A., Ezzahar, J. Erraki, S., Hoedjes, J., Hadria, R., Abourida, H., Cheggour, A., Raibi, F., Boudhar, A. Hanich, L., Guemouria, N., Chehbouni, Ah., Olioso, A., Jacob, F., Sobrino, J., 2008. An integrated modelling and remote sensing approach for hydrological study in semi-arid regions: the SUDMED Program. International Journal of Remote Sensing 29, 5161-5181.

De Solan, B. Chaponnière, A., Maisongrande, P., Duchemin, B., Hanich, L., Chehbouni, G., 2002.In: Cartographie de l'enneigement par télédétection à partir d'images SPOT-VEGETATION et Landsat-TM: application a 'l'Atlas marocain, Séminaire international, Hydrologie nivale en méditerrané, December 2002, Beyrouth, Lebanon.

Duchemin, B., Maisongrande, P., 2002. Normalisation of directional effects in 10-day global syntheses derived from VEGETATION/SPOT: I. Investigation of concepts based on simulation. Remote Sensing of Environment 81, 90-100.

Hagolle, O., Lobo, A., Maisongrande, P., Cabot, F., Duchemin, B., De Pereyra, A., 2005 Quality assessment and improvement of temporally composited products of remotely sensed imagery by combination of VEGETATION 1 \& 2 images. Remote Sensing of Environment 94, 172-186.

Hanich, L., de Solan, B., Duchemin, B., Maisongrande, P., Chaponnière, A., Boulet, G., Chehbouni, G., 2003. Snow covers mapping using SPOT-VEGETATION with high 
resolution data: application in the Moroccan Atlas Mountains. In: Proceedings of IEEE International Geoscience and Remote Sensing Symposium (IGARSS) 21-25 July 2003, Toulouse, France.

Hurrell, J.W., 1995. Decadal trends in the North Atlantic oscillation: regional temperatures and precipitation. Science 269 (5224), 676-679.

Kalnay, E., Kanamitsu, M., Kistler, R., Collins, W., Deaven, D., Gandin, L., Iredell, M. Saha, S., White, G., Woollen, J., Zhu, Y., Chelliah, M., Ebisuzaki, W., Higgins, W. Janowiak, J., Mo, K.C., Ropelewski, C., Wang, J., Leetmaa, A., Reynolds, R., Jenne, R., Joseph, D., 1996. The NCEP /NCAR 40-Year Reanalysis Project. Bulletin of the American Meteorological Society 77, 437-471.

Knippertz, P., Christoph, M., Speth, P., 2003. Long-term precipitation variability in Morocco and the link to the large-scale circulation in recent and future climates. Meteorology and Atmospheric Physics 83 (1-2), 67-88, doi:10.1007/s00703002-561-y

Lissens, G., Kempeneers, P., Fierens, F., 2000. Development of a cloud, snow and cloud shadow mask for VEGETATION imagery. In: Proceedings of VEGETATION Symposium, 3-6 April 2000, Lake Maggiore, Italy.

Liston, G.E., 1999. Interrelationships among snow distribution, snowmelt, and snow cover depletion: implications for atmospheric, hydrologic, and ecologic modeling. Journal of Applied Meteorology 38, 1474-1487.
Maisongrande, P., Duchemin, B., Dedieu, G., 2004. VEGETATION/SPOT: an operational mission for the Earth monitoring; presentation of new standard products. International Journal of Remote Sensing 25, 9-14.

Rosenthal, W., Dozier, J., 1996. Automated mapping of montane snow cover at subpixel resolution from the Landsat Thematic Mapper. Water Resources Research 32, 115-130.

Salomonson, V.V., Appel, I., 2004. Estimating the fractional snow cover using the normalized difference snow index. Remote Sensing of Environment 89, 351-360.

Schulz, O., De Jong, C., 2004. Snowmelt and sublimation: field experiments and modelling in the High Atlas Mountains of Morocco. Hydrology and Earth System Sciences 8, 1076-1089.

Shaban, A., Faour, G., Khawlie, M., Abdallah, Ch., 2004. Remote sensing application to estimate the volume of water in the form of snow on Mount Lebanon. Hydrological Sciences Journal 49, 611-621.

Simpson, J., Stitt, J., Sienko, M., 1998. Improved estimates of the areal extent of snow cover from AVHRR data. Journal of Hydrology 204, 1-23.

Von Storch, H., Zwiers, F.W., 1999. Statistical Analysis in Climate Research. Cambridge University Press, 484 pp.

World Bank, 1995. Kingdom of Morocco, a water sector review, Report No. 14750MOR.http://web.worldbank.org/. 